\title{
Findings of parasitological and Doppler echocardiographic examination in dogs with heartworm disease
}

\author{
Murat KİBAR ${ }^{1}$, Öznur ASLAN ${ }^{2}$, Alparslan YILDIRIM ${ }^{3}$ \\ ${ }^{1}$ Kyrgysh Turkish Manas University, Faculty of Veterinary Medicine, Department of Surgery, Bishkek, Kyrgyzstan; Erciyes \\ University, Faculty of Veterinary Medicine, ${ }^{2}$ Department of Internal Medicine, ${ }^{3}$ Department of Parasitology, Kayseri, Turkey.
}

\begin{abstract}
Summary: The purpose of the study reported here was to determine echocardiographic findings in naturally heartworminfected dogs, and evaluate these findings to use in the diagnosis of adult worms in the pulmonary artery. Sixteen male dogs (8.8\%) of the $180 \mathrm{dogs}$ in our study, weighing 7.5-42.0 kg, ranging in age from 1 to 8 years, were determined to be positive for Dirofilaria immitis according to the results of membrane filtration and antigen ELISA tests. Dogs identified with adult heartworms in their blood were evaluated by parasitological. The mean worm burden in infected dogs was $4730 \pm 5479$ (min: 8, max: 13.339) per ml of blood. Two-dimensional echocardiography showed a various number of heartworm echoes in the pulmonary artery in infected dogs. No worm was detected in right atrium. Various pulsed Doppler wave patterns were identified, and we classified them into 4 different types according to their pattern of wave dispersion. In conclusion, echocardiographic detection of worms in this location is strongly suggestive of heartworm disease.
\end{abstract}

Keywords: Dog, Doppler echocardiography, heartworm.

\section{Kalp kurdu ile enfekte köpeklerde parazitolojik ve Doppler ekokardiografik muayene bulguları}

Özet: Bu çalışmanın amacı, doğal olarak kalp kurdu ile enfekte köpeklerde ekokardiografik muayene bulgularını belirlemek ve bu bulguların pulmoner arterdeki erişkin kurtların tanısında kullanılabilirliğini değerlendirmektir. Tarama yapılan 180 köpekten ağırlıkları 7,5-42.0 kg, yaşları 1 ile 8 arasında değişen16 $(\% 8,8)$ erkek köpek membrane filtrasyon ve antijen ELISA testi ile Dirofilaria immitis yönünden pozitif olarak belirlendi. Bu köpekler ekokardiografik muayene ile değerlendirildi. Enfekte köpeklerde mikrofiler sayısı her mililitre kan için ortalama $4730 \pm 5479$ (min: 8, mak: 13.339) idi. İki boyutlu (2-D) ekokardiografi, enfekte köpeklerde pulmoner arterde çok sayıda kalp kurdu nedenli ekojenik yapılar gösterdi. Sağ atriumda kurt belirlenmedi. Değişik Doppler akım örnekleri belirlendi ve bunlar dalga şekillerine göre 4 tipte sınıflandırıldı. Sonuç olarak, kurtçukların yerleşiminin ekokardiografi ile belirlenmesi kalp kurdu hastalığını çok güçlü bir şekilde işaret etmektedir.

Anahtar sözcükler: Doppler ekokardiografi, kalp kurdu, köpek.

\section{Introduction}

Heartworm (HW) infection is primarily a disease of the pulmonary arterial vasculature and is the most common cause of pulmonary hypertension in dogs. The severity of disease is related to the number of worms present, the duration of the infection, and the host response $(7,13)$. Heartworm disease (HD) is common in highly HW endemic regions and seen in male dogs with an average age of 5 years old, in the spring to early summer $(14,16,23)$.

Dogs with HD will have pulmonary hypertension associated with pulmonary embolism caused by dead HWs or increased pulmonary vascular resistance induced by proliferative lesions in the intima and media of the pulmonary artery caused by the irritation of HWs $(4,8$, 23). As a result of increased pressure, the pulmonary arteries become dilated and tortuous, especially in the caudal and accessory lobes. The increased afterload induces right ventricular hypertrophy, which may progress to myocardial failure and right sided congestive heart failure (19).

Doppler echocardiography complements the dimensional and functional information obtained from 2Dimensional (2-D) and M-mode echocardiography by providing hemodynamic data for clinical cardiac evaluation (6). In 2-D and M-mode echocardiography, HW infection is characterized a large worm mass in the right ventricular lumen detectable during diastole (2). Echocardiographic findings may include variable right ventricular dilation and reduced contractility, right atrial enlargement, pulmonic valve insufficiency, and enlargement of the main pulmonary artery. Interventricular septal thickening and flattening also can be in some cases $(2,13)$. 
The purpose of the study reported here was to determine echocardiographic findings in naturally heartworm-infected dogs, and to determine the usefulness of echocardiography in the diagnosis of heartworm disease in dogs and evaluate this modality with other tests.

\section{Materials and Methods}

A total of 180 dogs with controlled filariae in their blood were randomly selected. Blood samples were collected from the vena cephalica antebrachii into heparinized $(5 \mathrm{ml})$ and serum $(2 \mathrm{ml})$ vacutainer tubes. The polycarbonate membrane filtration $(25 \mathrm{~mm}$ diameter- $5 \mu \mathrm{m}$ pore size; Millipore, TMTP 02500) technique was applied for the detection of circulating microfilariae (1). Sixteen male dogs $(8.8 \%)$ with a mean body weight of $23 \mathrm{~kg}$ (range, 7.5 to $42 \mathrm{~kg}$ ), ranging in age from 1 to 8 years, were subjected to this study. DiroCHECK ${ }^{\circledR}$ Lab Pack Heartworm Antigen kits (Synbiotics Corp., 96-0230) were used for detection and to examine the serum sample of the sexually-mature female worms. All samples were obtained during the day.

Dogs who identified as having adult heartworms in their blood were evaluated by echocardiography. After a 10 to 20 minute period of acclimation, a 4.0-7.0 $\mathrm{MHz}$ multi frequency probe, placed on the right precordium was used to obtain an echo and simultaneous ECG from dogs positioned in right lateral recumbency. Dogs were not given a sedative or anesthetic agent. By setting the echo window at the middle between the sternal border and the costochondral junction of the left 3rd to 5th intercostal spaces, the short-axis view of the bifurcation of the pulmonary artery or the long-axis view of the right ventricular outflow tract was determined. The beam was then angled toward the heart base, such that the pulmonary valve and trunk were viewed. The diameter of the right ventricular outflow tract was measured at the ventricular attachment of the valve in a plane where the vessel size appeared maximal (Figure 1).

Doppler echocardiographic findings were obtained using the same probe position and orientation used for imaging the region. The direction of the Doppler beam was oriented as parallel as possible to the presumed direction of blood flow. 200-400 Hz the range was used for the wall filter. In order to provide the maximum flow velocity pattern and abstain from the use of artifacts, the pulse repetition frequency was used adequately within the range 4-10 MHz. The sample volume (SV) was set at $1 \mathrm{~mm}$ in length. It was initially positioned near the center of the pulmonary valve orifice, and modified slightly when necessary to obtain the maximum flow velocity pattern by use of color flow ultrasonography (Figure 2) and the pulsed wave Doppler method. Average values were calculated to 3 cycles.

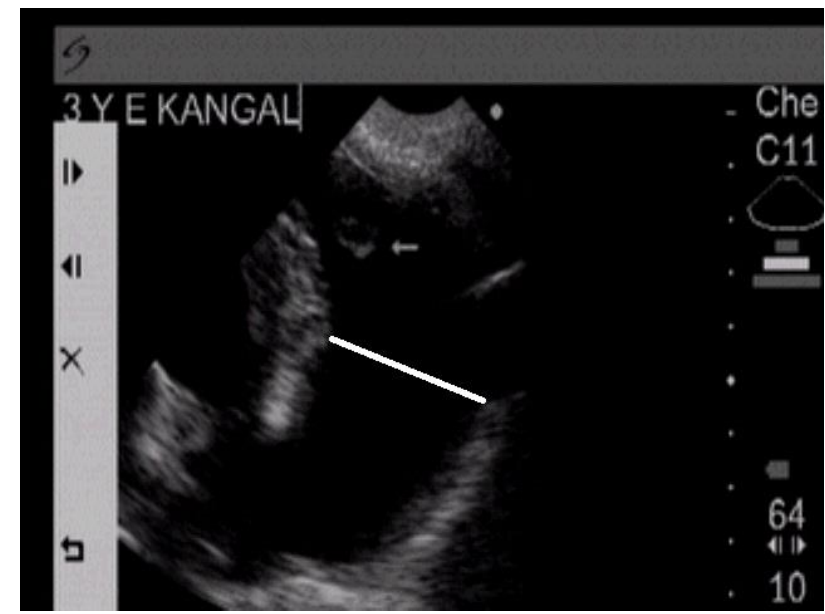

Figure 1. Diameter of the right ventricular outflow tract. Noted the vessel size appeared maximal (white line).

Şekil 1. Sağ ventrikül çıkışı çapı. Damar çapı maksimal görünümüne belirgindir (beyaz çizgi).

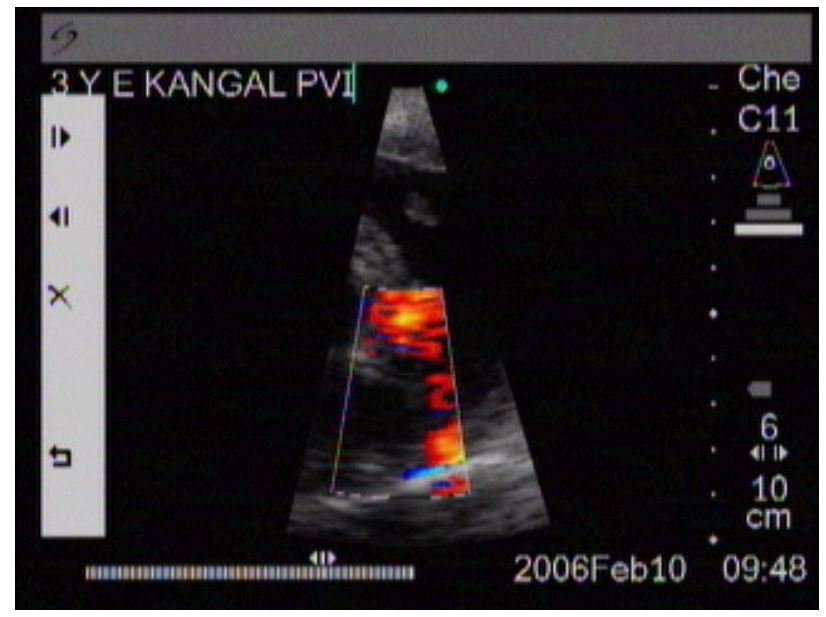

Figure 2. Color Doppler imaging of pulmonar valve regurgitation which is wide origin jet crosses the pulmonar valve and enters the right ventricle.

Şekil 2. Geniş jet akımı görüntüsü ve sağ ventrikül içine uzanan renkli Doppler pulmoner kapak kaçak akım görüntüsü.

\section{Results}

Of the 180 dogs examined, 16 (8.8\%) were determined to be positive for $D$. immitis according to the results of membrane filtration and antigen ELISA tests. The mean microfilarial burden in infected dogs was 4730 \pm 5479 (min: 8, max: 13.933) per ml of blood.

Physical examination revealed severe dehydration, pale mucous membranes, severe dyspnea, severe ascites, occasional cough, exercise intolerance, and a striking systolic murmur in the tricuspid valve region. Hypokinetic femoral pulses and jugular venous distention were observed in affected dogs. The mean heart rate of dogs with HD was high and heart auscultation displayed a grade IV/VI systolic regurgitant murmur on the right apex.

Some biochemical values were mildly increased such as ALT $(58.88 \pm 5.83)$, AST $(49.08 \pm 7.58)$, and GGT $(9.83 \pm 2.80)$. One hundred and twenty-eight 
(71.1\%) dogs did not receive prophylaxis and $52(28.9 \%)$ did receive prophylaxis at the time of blood sampling.

Two-dimensional echocardiography showed a various number of HW echoes in the pulmonary artery in infected dogs. No worm was detected in right atrium.

M-mode echocardiography, with cursor placement determined by use of 2-D echocardiography, were achieved for the 3 standard positions: at the level of $\mathrm{m}$. papillaris in left ventricle, at the level of the anterior mitral valve leaflet, and at the aortic root. No echogenic mass was seen in the right ventricle during diastole. However, inspection of the 2-D views specified the echogenic mass in the pulmonary artery (Figures 3, 4, 5, 6). Additionally, reduced contractility, paradoxical septal motion of varying degrees, and normal to exaggerated right ventricular cranial wall motion were prominent in dogs (Figure 7).

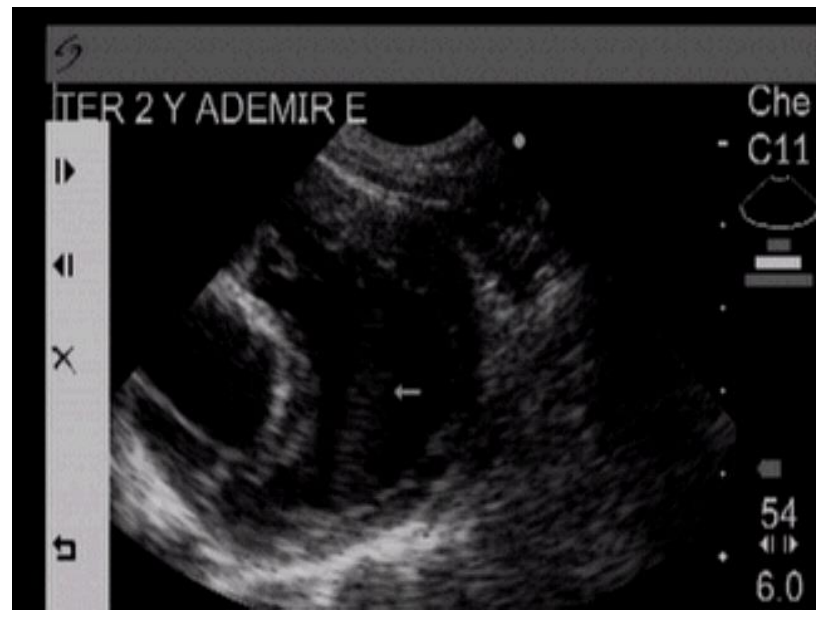

Figure 3. Two-dimensional echocardiogram is showed adult worms in the pulmonary artery. Worms are seen as parallel white lines (arrow).

Şekil 3. İki boyutlu ultrasonografi pulmoner arterdeki erişkin kurtları göstermektedir. Kurtlar paralel iki çizgi şeklinde izlenmekte (ok).

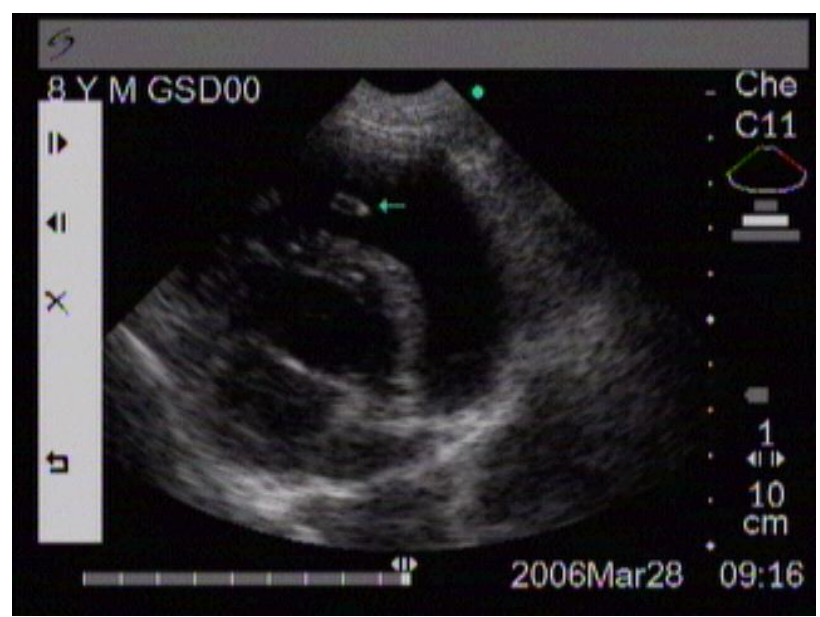

Figure 4. Noted the white lines (arrow), which is determined worm, in pulmonary artery.

Şekil 4. Kurt olarak belirlenen, pulmoner arterdeki beyaz çizgilere dikkat ediniz (ok).

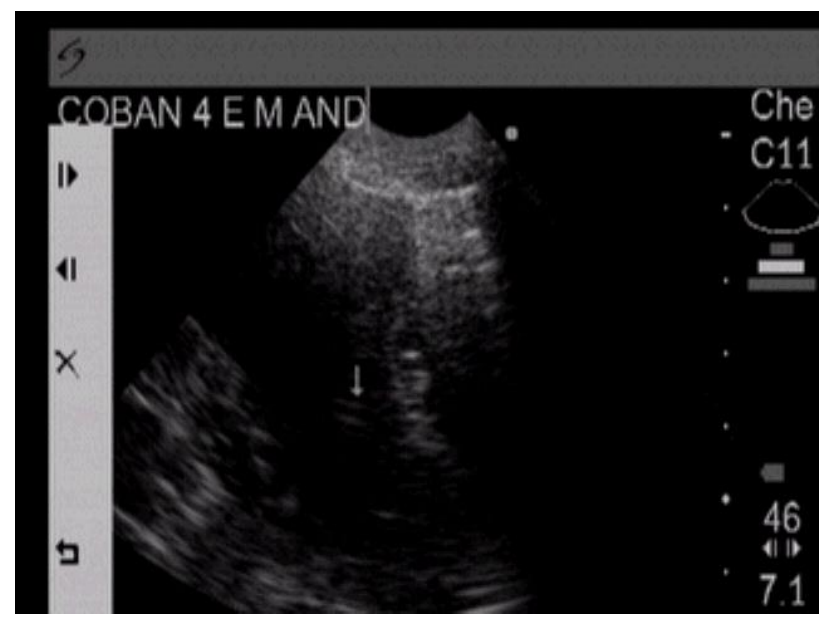

Figure 5. Noted the adult worm (arrow) which is seen as parallel white lines.

Şekil 5. İki paralel çizgi olarak görülen erişkin kurta dikkat ediniz (ok).

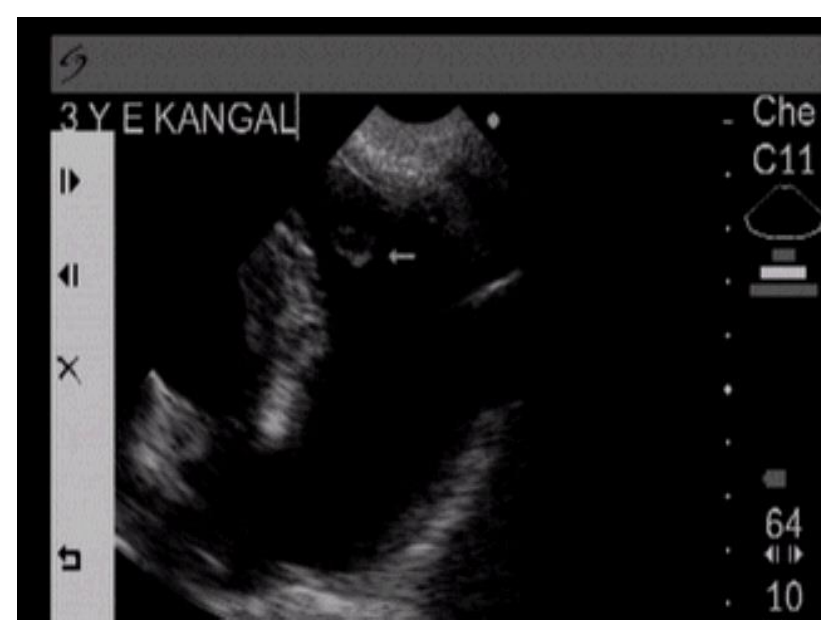

Figure 6. Two dimensional echocardiogram is demonstrated adult worm in right parasternal short axis view (arrow).

Şekil 6. Sağ parasternal kısa eksen 2D ultrasonografi görüntüsü erişkin kurdu göstermektedir (ok).

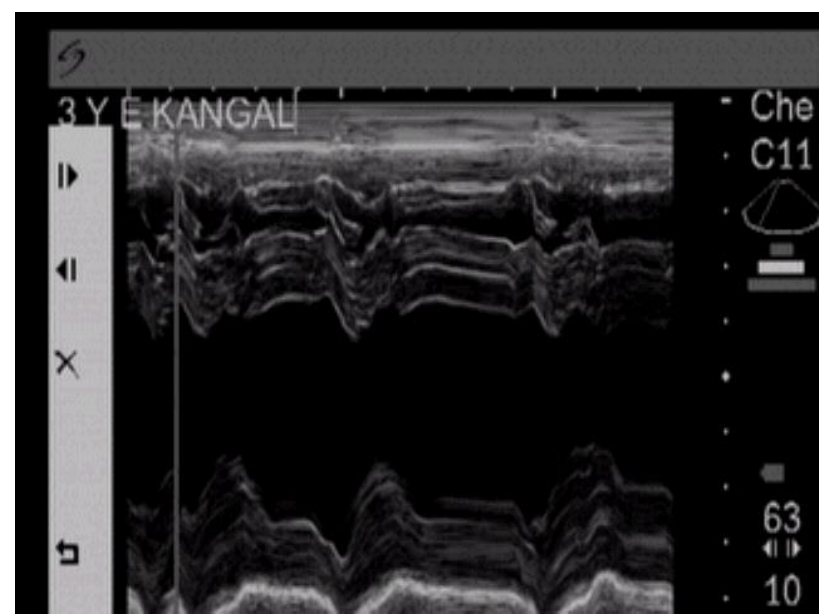

Figure 7. M-mod echocardiogram is showed paradoxical septal motion.

Şekil 7. M-mod ekokardiogram asimetrik septal hareketi göstermektedir. 
Various pulsed Doppler wave patterns were identified, and classified into 4 different types according to their pattern of wave dispersion. Type I-IV indicated normal, mild, moderate and severe pulmonary artery pressure (Figure 8). In addition, Doppler ultrasonography recognized a tricuspid regurgitation jet (Figure 9).

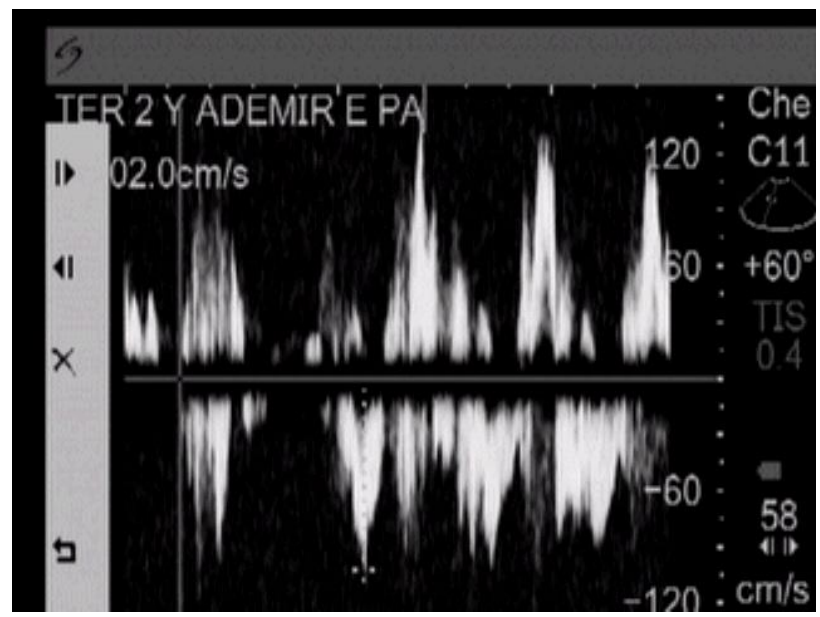

Figure 8. Noted the pulmonary flow type-III on pulsed wave Doppler echocardiogram (arrow).

Şekil 8. Kesikli dalga Doppler ekokardiogramda izlenen tip III pulmoner akım tipi görülmektedir (ok).

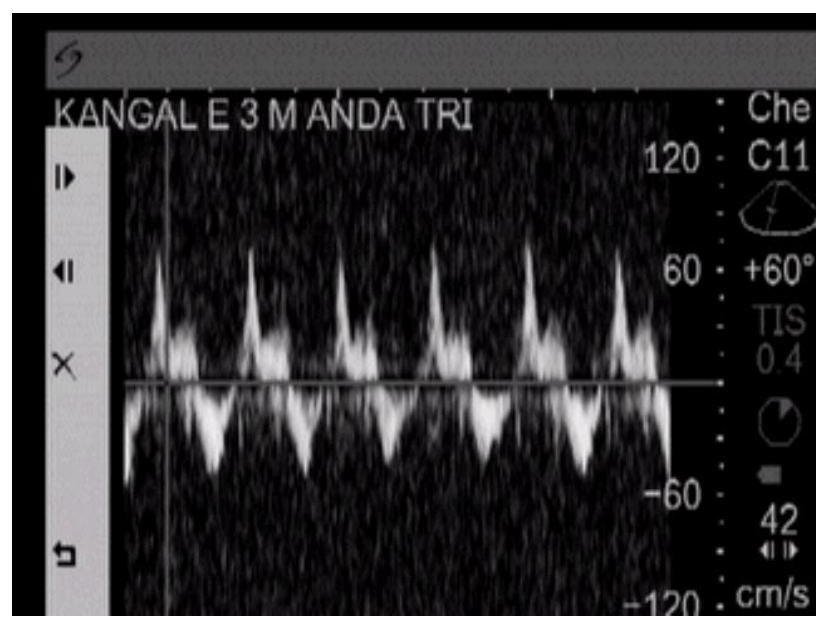

Figure 9. Determination of jet flow on tricuspidal valve by pulsed wave Doppler echocardiography (arrow).

Şekil 9. Kesikli dalga Doppler ekokardiyografi ile trikuspital kapak düzeyinde belirlenen jet akım (ok).

\section{Discussion and Conclusion}

The pathophysiologic mechanism of heartworm disease has been well-studied and was recently reviewed. Chronic HD results in right ventricular hypertrophy and dilatation subsequent to pulmonary hypertension caused by $D$. immitis induced damage to pulmonary arteries (2). This damage consisted of endarteritis, villous endothelial proliferation, and the formation of pulmonary thromboembolism (21). In dogs with severe HD of long duration, this chronic pressure load on the right ventricle may result in right sided heart failure.
Most dogs with heartworm disease display an acute disease course, and signs of severe anemia, liver injury, renal dysfunction, cardiac congestion and intravascular hemolysis $(5,15)$. In the present study, the laboratory data of most of the dogs indicated various organ malfunction. Some dogs demonstrated chronic signs of HD such as shortness of breath, exercise intolerance and long term ascites. These dogs were inclined to house a smaller number of adult HWs and to have a higher pulmonary artery pressure, and mildly higher plasma enzyme activities (15). These findings proposed that dogs infected with heartworm involved various stages, with almost normal to severely troubled circulation.

Obstructive lesions in the pulmonary artery associated with proliferated intima and medium of the artery are considered to be the main causes of the development of pulmonary hypertension in dogs (23).

The literature indicates the youngest age for spontaneous HW in dogs is 18 months (13). Experimental HW infection has been induced as early as 7 months after inoculation with a large number of infective larvae $(2,13)$. Each dog had lived through at least two mosquito seasons.

It is interesting that the worms have such a short life span; they live approximately 5 years, ranging from 3 to 7 years $(10,13)$. None of these dogs had a history of adulticide treatment. The reason for this is unknown, but the host's immune response to HWs might have been intense in the dogs reported here, as seen in feline HD $(10,13)$.

The result of this study corroborated the findings of others $(2,3)$, who reported evidence of chronic HW and pulmonary hypertension in dogs afflicted with HW. It was found that in the dogs of our study, right ventricular end diastolic diameter, volume, and volume index were increased suggesting chronic pulmonary hypertension and/or tricuspid valve regurgitation $(2,17,18)$. In addition, the right ventricular cranial wall was thick, the right ventricular papillary muscles were prominent, and some degree of paradoxical septal motion was identified.

The HW mass, displayed by 2-D echocardiography, was placed in the pulmonary artery. The results of this study and findings in dogs with naturally acquired heartworm disease suggest that this echocardiography finding, monitored in the proper clinical setting, is actually pathognomonic for HD (3).

It was concluded that abnormal septal motion, associated with right ventricular volume and pressure overloading, developed in humans when the ratio of left to right ventricular diastolic diameters decreases to $<1.5$ (2). The position and shape of the septum at end diastole was determined, in part, by the inter-ventricular pressure gradient $(2,9)$. Paradoxical septal motion was caused by, among other things, increases in right ventricular pressure and volume loading with resultant diastolic 
septal flattening and left ward distortion (2). When right ventricular end diastolic pressure exceeded left ventricular end diastolic pressure, diastolic left ward septal distortion was followed by right ward or paradoxical septal motion after systolic equalization of interventricular pressures (9). The effect of paradoxical septal motion on cardiac function is complex and potentially important (2). This effect was determined to be intensified in dogs with HW by the decrease in diastolic duration resulting from increased heart rate.

Signs of heart failure such as weak femoral pulses, cold extremities, pale mucous membranes, and poor capillary refill time in this model of HD are best explained by reduction in left ventricular preload caused indirectly by the effects of tricuspid valve regurgitation and pulmonary hypertension on the right ventricle ( 7 , 16). This explanation was strongly supported by the finding of marked reduction in mean left atrial dimension, both observed with the development of HD.

Retrograde migration of HWs from the pulmonary arteries is induced by decreases in cardiac output and velocity, associated with pulmonary arterial embolism of dead worms and/or shock like reaction caused by worm body extracts $(13,15)$. In addition, it is suggested that thromboembolism is formed after worm death and is the most important factor causing an increase in pulmonary arterial pressure (22), leading to a decline in cardiac output (13). In our cases, pathological examinations also demonstrated pulmonary embolism associated with dead worms and thrombi.

Findings show that the pulmonary orifice is more difficult to evaluate using standard 2-D echocardiography methods because the right ventricular outflow tract is oriented parallel, rather than perpendicular, to the direction of the ultrasound beam. Measurement accuracy is, therefore, limited by the lateral resolution of the 2-D image, which is inferior to the depth resolution. Nevertheless, the pulmonary outflow tract is more easily imaged noninvasively in the dog than in man, and distinct valvular attachments can often be seen marking the internal limits of the orifice (6). In this study, pulmonary flow was overestimated relative to aortic activity, although it cannot be stated which was more accurate.

Calculation of the actual velocity when flow is not parallel with the ultrasound beam may require an angle correction. In practice, an attempt should made to position the transducer so the beam is aligned with the direction of flow. When the actual angle between the beam and the flow is less than $25^{\circ}$, the assumption of zero angle used here results in $<10 \%$ underestimation of the velocity (6).

At each instance during the ejection phase, axial velocity over the vessel cross section ranged from zero at the vessel wall to a maximal value somewhere in the lumen. This range may be apparent as broadening of the velocity spectrum in the power Doppler is displayed. For pulmonary flow, the normal velocity profile across the lumen is relatively flat, so that the spatial maximum is also an estimate of the average axial velocity $(6,20)$. Determination of the maximum velocity across the lumen is also less subject to variations in sample volume positioning $(6,11)$. Therefore, this was the measurement used in this study to approximate the average over the cross section.

Pulmonary regurgitation was a common occurrence $(54 \%)$ in the population sample. From a clinical standpoint, this finding does not seem functionally important, considering the absence of corresponding audible murmurs and the minimal Doppler signal strength for the regurgitation flow. The result serves to alert investigators to the frequency of mild pulmonary regurgitation in clinically normal dogs. Doppler echocardiography is more sensitive than auscultation for detecting small amounts of valvular regurgitation $(6,12$, 24). Despite these considerations, Doppler echocardiography provides a useful, noninvasive method for estimating hemodynamic variables previously obtainable only by cardiac catheterization or other invasive procedures (12).

The SV has been adjusted to various positions in previous studies, some researchers used a site just under the orifice of the pulmonary valve and at the center of the pulmonary artery $(11,12)$. In this study, the SV was located preliminarily at the center of the pulmonary valve orifice, and a cross-section providing a good image of pulmonary artery flow was obtained by fine adjustment using the color Doppler procedure. Subsequently, the site of the SV was modified when necessary. This method is more favorable than the usual one involving setting by the pulsed Doppler method alone in that it allows simpler and faster determination of the blood flow (11).

It has been reported that various pulmonary artery flow hemodynamics have such a prominent dome-like and sharper pattern, and that the pattern actually changes to a pointed wave form with a peak shifted to an earlier phase, while the latter half of the wave form is completely lost (25). In the present study, a similar trend was received, and the pulmonary artery flow velocity patterns demonstrated 4 types of variation.

Another method for evaluating pulmonary artery pressure is also meaningful in this discussion. Tricuspid regurgitation can also be determined by the continuous wave Doppler method. Here, the right atrial pressure differentiation is computed from the maximum flow velocity of regurgitation according to Bernoulli's law. This value is then added to the assumed right atrial pressure to obtain the systolic right ventricular pressure, i.e., systolic pulmonary artery pressure. This method is used both in humans and $\operatorname{dogs}(7,16,25)$. It should be 
stated that this method requires the determination of tricuspid regurgitation. Errors of measurement may occur theoretically if the maximum flow velocity is not correctly detected.

In summary, HD is participated by retrograde migration of a large worm burden to the right heart side. Echocardiographic detection of worms in this location is strongly suggestive of $\mathrm{HD}$. In addition to the physical presence of the worm mass, chronic heartworm induced changes in right ventricular geometric configuration may interfere with cooptation of the tricuspid valve leaflets resulting in valvular insufficiency. This study clearly suggests that the pulmonary arteries must be evaluated carefully to increase the likelihood of detection of HWs echocardiographically.

\section{References}

1. Acevedo RA, Ciencias L, Theis JE, et al. (1981): Combination of filtration and histochemical stain for detection and differentiation of Dirofilaria immitis and Dipetalonema reconditim in the dog. Am J Vet Res, 40, 537-540.

2. Atkins CE, Keene BW, McGuirk SM (1988): Pathophysiologic mechanism of cardiac dysfunction in experimentally induced heartworm caval syndrome in dogs: An echocardiographic study. Am J Vet Res, 49, 403410.

3. Atkins CE, Keene BW, McGuirk SM (1988): Investigation of caval syndrome in dogs experimentally infected with Dirofilaria immitis. J Vet Intern Med, 2, 3640.

4. Atkins CE (1987): Heartworm caval syndrome in the dog. Semin Vet Med Surg, 2, 64-71.

5. Atwell RB, Buoro IBJ (1988): Caval syndrome. 191-203. In: Boreham PFL, Atwell RB (Eds), Dirofilariasis. CRC Pres, Boca Raton.

6. Brown DJ, Knight DH, King RR (1991): Use of pulsedwave Doppler echocardiography to determine aortic and pulmonary velocity and flow variables in clinically normal dogs. Am J Vet Res, 52, 543-550.

7. Calvert CA, Rawlings CA, McCall JW (1999): Canine heartworm disease. 702-726. In: Fox PR, Sisson D, Moise NS (Eds), Textbook of Canine and Feline Cardiology. WB Saunders, Philadelphia.

8. Clarence RA (1980): Acute response of pulmonary blood flow and right ventricular function to dirofilaria immitis adults and microfilaria. Am J Vet Res, 41, 244-249.

9. DeMadrone E, Bonagura JB, O'Grady MR (1985): Normal and paradoxical septal motion in the dog. Am $\mathrm{J}$ Vet Res, 46, 1832-1841.

10. Dillon R (2000): Dirofilariasis in dogs and cats. 937-963. In: Ettinger SJ, Feldman EC (Eds), Textbook of Veterinary Internal Medicine. WB Saunders, Philadelphia.

11. Evans DH (1985): On the measurement of the mean velocity of blood flow over the cardiac cycle using Doppler ultrasound. Ultrasound Med Biol, 11, 735-741.
12. Hatle L, Angelsen B (1982): Doppler Ultrasound in Cardiology: Physical Principles and Clinical Applications. Lea and Febiger. Philadelphia, USA.

13. Hidaka Y, Hagio M, Murakami T, et al. (2003): Three dogs under 2 years of age with heartworm caval syndrome. J Vet Med Sci, 65, 1147-1149.

14. Kitagawa H, Sasaki Y, Ishihara K, et al. (1991): Cardiopulmonary function values before and after heartworm removal in dogs with caval syndrome. $\mathrm{J}$ Am Vet Sci, 52, 126-132.

15. Kitagawa H, Kitoh K, Iwasaki T, et al. (1997): Comparison of laboratory data in dogs with heartworm caval syndrome surviving and non-surviving after surgical treatment. J Vet Med Sci, 59, 609-611.

16. Kittleson MD (1998): Heartworm disease. 340-401. In: Kittleson MD, Kienle RD (Eds), Small Animal Cardiovascular Medicine. Mosby, St Louis.

17. Lombard CW, Buergelt CD (1983): Echocardiographic and clinical findings in dogs with heartworm-induced cor pulmonale. Compend Contin Educ Pract Vet, 5, 971-979.

18. Lombard CW, Ackerman N (1984): Right heart enlargement in heartworm-infected dogs. Vet Radiol, 25, 210-217.

19. Munnell JF, Weldom JS, Lewis RE, et al. (1980): Intimal lesions of the pulmonary artery in dogs with experimental Dirofilariasis. Am J Vet Res, 41, 1108-1112.

20. Paulsen PK, Hasenkam JM (1983): Three-dimensional visualization of velocity profiles in the ascending aorta in dogs, measured with a hot film anemometer. J Biomech, 16, 201-210.

21. Rawlings CA, Keith JC, Schaub RG (1981): Development and resolution of pulmonary disease in heartworm infection: illustrated review. J Am Anim Hosp Assoc, 17, 711-720.

22. Sasaki Y, Kitagawa H, Hirano Y (1992): Relationship between pulmonary arterial pressure and lesions in the pulmonary arteries and parenchyma, and cardiac valves in canine dirofilariasis. J Vet Med Sci, 54, 739-44.

23. Sihibata T, Wakao Y, Takahashi M (2000): A clinical study on velocity patterns of pulmonary venous flow in canine heartworm disease. J Vet Med Sci, 62, 169-177.

24. Takemura N (1989): Changes in the canine cardiac function associated with heartworm disease-effect of proliferation of bronchoesophageal artery on pulmonary artery. Jpn J Electrocardiol, 42, 771-773.

25. Uehara Y (1993): An attemp to estimate the pulmonary artery pressure in dogs by means of pulsed Doppler echocardiography. J Vet Med Sci, 55, 307-312.

Geliş tarihi: 24.04.2015 / Kabul tarihi:11.11.2015
Address for correspondence:
Prof. Dr. Murat KIBAR,
Kyrgysh Turkish Manas University,
Faculty of Veterinary Medicine,
Department of Surgery,
72004, Bishkek/Kyrgyzstan
e-mail:muratkibartr@yahoo.com 